\title{
INHIBITION OF QUORUM SENSING BY DRIMANE LACTONES FROM CHILEAN FLORA
}

\author{
${ }^{1}$ GERARDO CÁRCAMO, ${ }^{2}$ MARIO SILVA, ${ }^{2}$ JOSÉ BECERRA, ${ }^{1}$ HOMERO URRUTIA, \\ ${ }^{3}$ KATHERINE SOSSA AND ${ }^{4}$ CRISTIAN PAZ*
}

\author{
${ }^{1}$ Department of Microbiology and Biotechnology Center, University of Concepción, Chile \\ ${ }^{2}$ Laboratory of Chemistry of Natural Products, University of Concepción, Chile \\ ${ }^{3}$ Faculty of Forestry and Biotechnology Center, Universidad de Concepción, Chile \\ ${ }^{4}$ Department of Chemistry and Natural Resources, Universidad de la Frontera, Chile
}

\begin{abstract}
Fifteen native Chilean plants were evaluated against the quorum sensing (QS) biosensor AI-1, Chromobacterium violaceum ATCC 12472 . Three extracts showed inhibitory activity of QS: Drymis winteri J.R. Psoralea glandulosa L and Peumus boldus. Purification of secondary metabolites from barks of Drimys winteri showed that drimane sesquiterpenes were the main compounds in the tree. Polygodial, drimenol, isodrimeninol, drimenin, isodrimenin, cinnamolide and valdiviolide were isolated and evaluated in QS inhibition assays. Two $\alpha, \beta$ unsaturated lactones, cinnamolide and valdiviolide, with the carbonyl on position 12 of the drimane skeleton were found to be inhibitors of QS; other drimane lactones were not active.
\end{abstract}

Keywords: Quorum sensing; Chromobacterium violaceum; Drimys winteri; Drimane sesquiterpenes.

\section{INTRODUCTION}

Quorum sensing is the communication system through which bacteria can regulate colonization, biofilm formation and virulence factors ${ }^{1}$. Bacteria produce small amounts of diffusible signal molecules, called autoinducers, such as acyl-homoserine lactones (HSL), oligopeptides, quinotones, cyclic dipeptides or diffusible signal factor (DSF). These signal molecules accumulate in the extracellular environment until they attain a critical threshold concentration, depending on cellular density, resulting in a cellular reaction that usually leads to gene expression².

Natural compounds are a source of bioactive molecules from which it is possible to find inhibitors of QS. For example: the microalgae Delisea pulchera produces furanones, which specifically interfere with the QS system mediated by HSL, garlic extract has shown a strong QS inhibitor activity on Pseudomonas aeruginosa and reduces the biofilm's tolerance to tobramycin treatment ${ }^{3}$, and vanilla extract (Vanilla planifolia, Andrews) is able to inhibit the QS of Chromobacterium violaceum ${ }^{4}$.

Chromobacterium violaceum is a gram negative bacterium that produces a pigment, violacein, regulated by the QS system. McLean et al. described a procedure to identify QS inhibitors using the coloration system of $C$. violaceum ${ }^{5}$. When compounds that inhibit $\mathrm{QS}$ are added to a culture of $C$. violaceum, the bacteria grow without producing the pigment, reflected as white colonies on the testing plate.

Screening of 50 medicinal plants (leaves and flowers) from south Florida, USA, has shown 6 plants with inhibitory QS activity; Conocarpus erectus L., Chamaecyce hypericifolia (L.) Millsp. Callistemon viminalis (Sol. ex Gaertn.) G. Don, Bucida burceras L., Tetrazygia bicolor (Mill.) Cogn. and Quercus virginiana Mill. ${ }^{6}$. Considering that in Chile, there are about 6,000 native plants, including both endemic natives and adventitia, which produce a wide variety of biologically active compounds ${ }^{7}$, there is great potential to find new activity by studying their QS effects.

\section{RESULTS AND DISCUSSION}

In this report we perform a QS inhibition study on the biosensor $C$. violaceum ATCC 12472 using ethyl acetate extracts from 15 native Chilean plants (Table 1). Drymis winteri J.R, Psoralea glandulosa L and Peumus boldus showed inhibitory activity of QS. Moreover, five plants showed biocide activity against the reporter strain; those plants are: Nothofagus pumilio, Podocarpus saligna, Salvia mellifera, Aristotelia chilensis and Lithrea caustic.
Table 1. Qualitative analysis of Chilean plants against $C$. violaceum ATCC 12472. QS and bactericide activity, Active (++), Inactive (--) at $100 \mu \mathrm{g} / \mathrm{disc}$

\begin{tabular}{|c|l|c|c|}
\hline Entry & \multicolumn{1}{|c|}{ Name } & QS activity & Biocide activity \\
\hline 1 & Aextoxicon punctatum & -- & -- \\
\hline 2 & Aristotelia chilensis & -- & ++ \\
\hline 3 & Cryptocarya alba & -- & -- \\
\hline 4 & Drimys winteri & +++ & -- \\
\hline 5 & Escallonia illinita Presl & -- & -- \\
\hline 6 & Gevuina avellana & -- & -- \\
\hline 7 & Lomatia hirsuta (Lam). & -- & -- \\
\hline 8 & Lithrea caustica & -- & ++ \\
\hline 9 & Nothofagus pumilio & -- & ++ \\
\hline 10 & Peumus boldus & ++ & -- \\
\hline 11 & Persea lingue & -- & +- \\
\hline 12 & Podocarpus saligna & -- & +- \\
\hline 13 & Psoralea glandulosa L. & ++ & +- \\
\hline 14 & Rhaphithamnus spinosus & -- & -- \\
\hline 15 & Salvia mellifera L & - & + \\
\hline & -- & - \\
\hline
\end{tabular}

The purification of secondary metabolites from barks of the most active plant Drimys winteri gave us seven known compounds with a drimane sesquiterpenoid skeleton (Figure 1), which were then evaluated in the QS system of $C$. Violaceum. Poygodial (1), the most bioactive compound in the plant $^{8}$, displayed bactericide properties on the strain but did not affect the QS system. Only two compounds; cinnamolide (6) and valdiviolide (7) displayed inhibitory activity of QS, with reduction of the pigment violacein at $54.3 \%$ and $43.7 \%$, respectively, using a concentration of sesquiterpene of $800 \mu \mathrm{g} / \mathrm{mL}$ (Figure 2). 
<smiles>CC1(C)CCC[C@]2(C)[C@@H](C=O)C(C=O)=CC[C@]12C</smiles>

(1) Polygodial<smiles>CC1=CC[C@]2(C)[C@@H](C)CCC[C@]2(C)[C@H]1CO</smiles>

(2) Drimenol<smiles>CC1(C)CCC[C@@]2(C)[C@H]3C(=CC[C@@]12C)CO[C@H]3O</smiles>

(3) Isodrimeninol<smiles>CC1(C)CCC[C@]2(C)[C@H]3C(=O)OCC3=CC[C@]12C</smiles>

(4) Drimenin<smiles>CC1(C)CCC[C@]2(C)C3=C(CC[C@]12C)COC3=O</smiles>

(5) Isodrimenin<smiles>CC1(C)CCC[C@@]2(C)[C@H]3COC(=O)C3=CC[C@]12C</smiles>

(6) Cinnamolide<smiles>CC1(C)CCC[C@]2(C)C3=C(CC[C@]12C)C(=O)O[C@H]3O</smiles>

(7) Valdiviolide

Figure 1: Sesquiterpenes isolated from bark of Drimys winteri

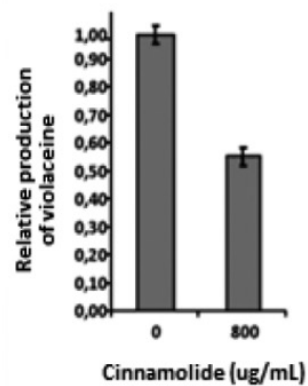

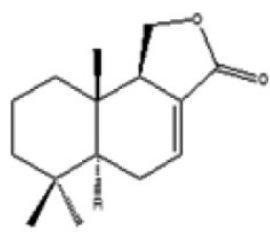

(6) Cinnamolide

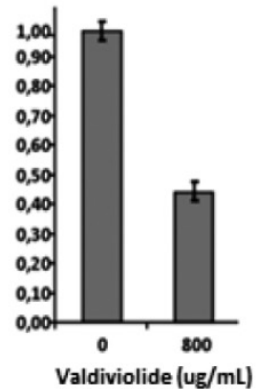

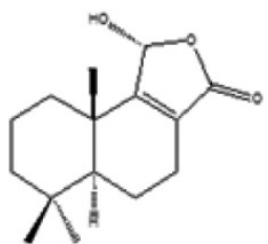

(7) Valdiviolide

Figure 2. Quantitative reduction of violacein by cinnamolide and valdiviolide $(n=3)$.

\section{CONCLUSIONS}

From fifteen Chilean plants; Aextoxicon punctatum, Aristotelia chilensis, Cryptocarya alba, Drimys winteri, Escallonia illinita, Gevuina avellana, Lomatia hirsuta, Lithrea caustica, Nothofagus pumilio, Peumus boldus, Persea lingue, Podocarpus saligna, Psoralea glandulosa, Rhaphithamnus and Salvia mellifera, just three plants have displayed inhibition of quorum sensing in the reporter strain C. violaceum ATCC 12472: Drymis winteri J.R, Psoralea glandulosa L and Peumus boldus. From the extract of Drymis winteri J.R were isolated seven known drimane sesquiterpenes and were evaluated against C. violaceum; Polygodial, drimenol, isodrimeninol, drimenin were inactive isodrimenin against the reporter strain but cinnamolide and valdiviolide have shown inhibitory activity of QS. Cinnamolide and valdiviolide are $\alpha \beta$ unsaturated lactones with the carbonyl on position 12 of the drimane skeleton, wheras drimenin, isodrimenin and isodrimeninol have the carbonyl group at position 11 and are not active. This relationship between structure and activity shows us the high specificity of the QS system.

\section{EXPERIMENTAL}

Plant extract: Samples of Escallonia illinita Presl, Rhaphithamnus spinosus, Peumus boldus, Psoralea glandulosa L, Nothofagus pumilio, Persea lingue, Podocarpus saligna D.Don, Salvia mellifera L, Aristotelia chilensis, Lithrea caustica, Gevuina avellana, Drimys winteri, Aextoxicon punctatum, Cryptocarya alba and Lomatia hirsute were collected from the gardens at the University of Concepción. $100 \mathrm{~g}$ of leaves were dried, powdered and continuously extracted on a Soxlet, using ethyl acetate as an organic solvent. After extraction the solvent was removed by vacuum leaving a gummy oil, which was stored at $4^{\circ} \mathrm{C}$

Bacterial strain: Chromobacterium violaceum 12472: This biosensor produces violacein under control of QS. This strain is maintained frozen in the bacterial collection of the Biotechnology Institute of the University of Concepción.
Drimane sesquiterpenes: $1 \mathrm{~kg}$ of bark from Drimys winteri was powdered and extracted by maceration with ethanol for 3 days. The solvent was filtered and concentrated by vacuum to obtain a dark oil; the maceration was carried out 3 times giving $20 \mathrm{~g}$ of crude, which was purified by preparative chromatography using a flash column with silica gel as a stationary face and hexane/ethyl acetate as solvents, obtaining 5 fractions. The first fraction corresponded to aromatic oils eluted with hexane. Increasing the polarity to $10 \%$ ethyl acetate resulted in the isolation of drimenol, drimenin and isodrimenin. After exposure to 20 to $30 \%$ ethyl acetate cinnamolide, polygodial (oil), isodrimeninol (oil) were isolated. In turn, valdiviolide was purified from the $40 \%$ ethyl acetate fraction. All compounds are known in the literature and were identified by comparison of ${ }^{1} \mathrm{H}-\mathrm{NMR}$ and ${ }^{13} \mathrm{C}-\mathrm{NMR}$ with bibliographic data ${ }^{9,10,11}$.

Qualitative QS inhibition: The assay was carried out against $C$. violaceum ATCC 12472 following the procedure described by McLean et al $l^{5}$. Plates with $20 \mathrm{~mL}$ of agar media LB were inoculated with $100 \mu \mathrm{L}$ of a bacterial culture of $C$. violaceum with a concentration of $10^{7} \mathrm{UFC} / \mathrm{mL}$. Compounds were impregnated on paper disks and placed on agar plates previously inoculated with the bacteria, and then were cultivated at $37^{\circ} \mathrm{C}$ over $24 \mathrm{~h}$. Inhibitors of QS were identified by bacterial growth without colour.

Violacein quantification: Quantitative evaluation of QS inhibitory activity was carried out following the procedure described by Blosser et al..$^{12}$, in which the pigment violacein is extracted in ethanol from liquid culture of $C$. violaceum ATCC 12472 and measured by molecular absorption at $585 \mathrm{~nm}$. The $100 \%$ value was assigned to the violacein concentration produced by control cultures grown without inhibitor $(n=3)$. Cultures grown in the presence of QS inhibitors, were extracted and measured at $585 \mathrm{~nm}$. The percentage of violacein inhibition was calculated following the formula: Percentage of violacein inhibition $=($ control OD585 nm - test OD585 nm/control OD585 nm $) \times 100$ 


\section{REFERENCES}

1. W. Fuqua, S. Winans, Greenberg E, Journal of Bacteriology, 176, 269 , (1994)

2. B. Lazazzera, A. Grossman, Trends in Microbiology, 7, 288, (1998)

3. T. Bovbjerg, T. Bjarnsholt, Journal of Bacterioloy, 187, 1799, (2005)

4. J. Choo, Y. Rukayadi, J. Hwang, Letters in Applied Microbiology, 42, 637, (2006)

5. R. McLean, L. Pierson, C. Fuqua, Journal of Microbiological Methods, 58, $351,(2004)$

6. A. Adonizio, K. Downum, B. Bennett, K. Mathee, Journal of Ethnopharmacology, 105, 427, (2006)

7. M. Silva, M. Bittner, P. Pacheco, Estudio químico de la familia Compositae del Archipiélago de Juan Fernández. Edit. Química de la flora de Chile, 1992.
8. I. Kubo, K. Fujita, S. Lee, T. Ha, Phytotherapy Research, 19, 1013, (2005)

9. B. Jansen, A. Groot, Natural Products Reports, 21, 449, (2004)

10. D. Hollinshead, C. Howell, S. Ley, M. Mahon, N. Ratcliffe, P. Worthington, Journal of. Chemistry Society, Perkin Transaction, 1, 1579, (1983)

11. R. Appel, K. Overton, Tetrahedron, 19, 635, (1963)

12. R. Blosser, K. Gray, Journal of Microbiological Methods, 40, 47, (2000)

\section{ACKNOWLEDGMENTS}

Financial support from the projects INNOVA BIOBIO 04-B1-321, DIUC 208.142.026.1.0, Mecesup UCH-0601, Anillo ACT-38 and Universidad de la Frontera are gratefully acknowledged. 